\title{
HOW DOES BIOCHAR AND BIOCHAR WITH NITROGEN FERTILIZATION INFLUENCE SOIL REACTION?
}

\author{
Vladimír Šimanský', Alan Klimaj² \\ 1 Department of Soil Science, Faculty of Agrobiology and Food Resources, Slovak University of Agriculture, Tr. \\ A. Hlinku 2, 94976 Nitra, Slovakia, e-mail:Vladimir.Simansky@uniag.sk \\ 2 Department of Landscape Engineering, Horticulture and Landscape Engineering Faculty, Slovak University \\ of Agriculture, Hospodárska 7, 94976 Nitra, Slovakia
}

Received: 2017.05.30

Accepted: 2017.08.01

Published: 2017.09.01

\begin{abstract}
Biochar usually has a neutralizing effect, therefore, it is recommended for application to acid soils due to its potential to increase soil $\mathrm{pH}$. The aims of this study were (1.) to quantify the role of different rates of biochar and biochar in combination with $\mathrm{N}$ fertilization on change of soil $\mathrm{pH}$, and (2.) to evaluate the dynamic changes of soil $\mathrm{pH}$ in relation with doses of biochar and biochar with $\mathrm{N}$ fertilization. A field experiment was conducted with different biochar application rates: B0 control (0 t ha $\left.{ }^{-1}\right), \mathrm{B} 10$ (10 $\left.\mathrm{t} \mathrm{ha}^{-1}\right)$ and B20 (20 tha $\left.\mathrm{h}^{-1}\right)$ and 0,40 and $80 \mathrm{~kg} \mathrm{~N} \mathrm{ha}^{-1}$ of nitrogen fertilizer (N0, N40, N80) on silt loam Haplic Luvisol at the locality of Dolná Malanta (Slovakia) in 2014. Their effects were investigated after vegetation season of spring barley and spring wheat (once a month: from April to July) in 2014 and 2016, respectively. Experimental results indicate that the soil $\mathrm{pH}_{\mathrm{H} 2 \mathrm{O}}$ in $\mathrm{B} 0 \mathrm{~N} 0, \mathrm{~B} 10 \mathrm{~N} 0, \mathrm{~B} 20 \mathrm{~N} 0, \mathrm{~B} 10 \mathrm{~N} 40, \mathrm{~B} 20 \mathrm{~N} 40$, $\mathrm{B} 10 \mathrm{~N} 80$ and $\mathrm{B} 20 \mathrm{~N} 80$ were $6.23,6.45,6.60,6.77,6.48,6.36$ and 6.60 , respectively. The results of LSD test showed statistically significant differences between soil $\mathrm{pH}$ in control treatment and treatments with biochar and biochar with $\mathrm{N}$ fertilization. The most significant effect on increase of soil $\mathrm{pH}$ was observed in B10N40. During whole period, after application of biochar and biochar with $\mathrm{N}$ fertilization the values of $\mathrm{pH}_{\mathrm{KCl}}$ were gradually decreased in all treatments.
\end{abstract}

Keywords: biochar, soil $\mathrm{pH}$, neutralizing effect, $\mathrm{N}$ fertilization.

\section{INTRODUCTION}

The reaction of soils is significant in crop production and soil management practices because the various degree of soil reaction are produced by the chemical conditions which exist in soils, each set of chemical conditions causing its corresponding degree reaction. Each degree of soil reaction or set of chemical conditions in soils affects plant growth in a certain way owing to either a depressed solubility of some elements or to an increased solubility of others. The chemical conditions which accompany the different degrees of soil reaction, therefore, may be favourable to the growth of some crops, unfavourable to others, and in still other cases they may affect plant growth very little [Millar et al. 1962, Hanes 1999, Čurlík et al. 2003]. In the framework of agrochemical testing of soils in Slovakia, the soil $\mathrm{pH}$ is one of the most important parameters which is monitored. According to the results of the last monitored cycle ASP (XII.), Slovakia had 23.4, $35.2,23.4$ and $18.0 \%$ of soils acid, slightly acid, neutral and alkaline reaction, respectively. Most crop plants requires the $\mathrm{pH}$ value of 6-7 because this interval corresponds to the requirements of releasing nutrients from soil stocks and keeping them in accessible forms [Fecenko and Ložek 2000], so we have to lime mainly acid soils.

For liming except classic $\mathrm{Ca}$ fertilizers can be used biochar due to its neutralizing effects, high content of alkaline metals and basic cations in ash 
[DeLuca et al. 2009, Yuan et al, 2011]. Effect of biochar on soil pH [Yuan et al. 2011, Zhang et al. 2012, Jones et al. 2012, Horák 2015] have been studied, but obtained results can be different due to different $\mathrm{pH}$ of biochar. The $\mathrm{pH}$ of biochar is influenced by the type of feedstock, production temperature, and production duration [Liu et al. 2012].

In this context, there are a few hypotheses: (1.) application of biochar to the soil would increase soil $\mathrm{pH}$, however its effect can effected by rate of biochar as well as by dose of $\mathrm{N}$ fertilization. Biochar is source of stabile organic matter [Fischer and Glaser 2012], so there is a premise that its alkalizing effect will be of a longer term nature. Therefore, the objectives of this study were (1.) to quantify the role of different rates of biochar and biochar in combination with $\mathrm{N}$ fertilization on change of soil $\mathrm{pH}$, and (2.) to evaluate the dynamic changes of soil $\mathrm{pH}$ in relation with doses of biochar and biochar with $\mathrm{N}$ fertilization.

\section{MATERIAL AND METHODS}

This study was carried out on an ongoing experiment with different application rates of biochar and its combination in different doses of $\mathrm{N}$ fertilization that had been running for three years at Dolná Malanta (48 $\left.19^{\prime} 00^{\prime \prime} \mathrm{N} ; 1^{\circ} 09^{\prime} 00^{\prime \prime} \mathrm{E}\right)$. The geological substratum consisted of little previous rocks (biotite, quartz, diorite, triassic quartzites with phyllite horizonts, crinoid limestones and sandy limestone) with high quantities of fine materials. Young Neogene deposits were composed of various clays, loams and sand gravels on which loess was deposited in the Pleistocene epoch. The soil was classified as the Haplic Luvisol [WRB 2006]. Soil organic carbon content was $9.13 \mathrm{~g} \mathrm{~kg}^{-1}$ and soil $\mathrm{pH}(\mathrm{KCl})$ was 5.71. Soil texture was silt loam with content of sand $15.2 \%$, silt $59.9 \%$ and clay $24.9 \%$. The mean annual precipitation in the region is $573 \mathrm{~mm}$ and the mean annual temperature is $9.8^{\circ} \mathrm{C}$.
The experiment was established in March 2014. More information about experiment was published by Šimanský et al. [2016]. The research comprised of seven treatments (Table 1) and the experiment was laid out in a randomized block design with three replicates.

The biochar was produced by pyrolysing paper fiber sludge and grain husks (1:1 w/w) (company Sonnenerde, Austria). Biomass was pyrolysed at $550{ }^{\circ} \mathrm{C}$ for 30 minutes in a Pyreg reactor (Pyreg $\mathrm{GmbH}$, Dörth, Germany). The result was product with particle size of $1-5 \mathrm{~mm}$. On average; it contained $57 \mathrm{~g} \mathrm{~kg}^{-1}$ of Ca, $3.9 \mathrm{~g} \mathrm{~kg}^{-1}$ of $\mathrm{Mg}, 15 \mathrm{~g} \mathrm{~kg}^{-1}$ of $\mathrm{K}$ and $0.77 \mathrm{~g} \mathrm{~kg}^{-1}$ of Na. Total C content of biochar was $53.1 \%$, while total $\mathrm{N}$ content was $1.4 \%$, the $\mathrm{C}: \mathrm{N}$ ratio was 37.9 , specific surface area (SSA) was $21.7 \mathrm{~m}^{2} \mathrm{~g}^{-1}$ and content of ash was $38.3 \%$. On average, the biochar $\mathrm{pH}\left(\mathrm{CaCl}_{2}\right)$ was 8.8. Calciumammonium nitrate was used as $\mathrm{N}$ fertilizer. The field was ploughed and biochar combined with or without $\mathrm{N}$ fertilization for all plots was incorporated to a depth of $10 \mathrm{~cm}$. The spring barley (Hordeum vulgare L.) and spring wheat (Triticum aestivum L.) were sown in 2014 and 2016, respectively.

The soil was sampled repeatedly from the top layer (0-20 cm depth) to cover the whole spring barley growing season $\left(17^{\text {th }}\right.$ April, $15^{\text {th }}$ May, $16^{\text {th }}$ June, and $13^{\text {th }}$ July) in 2014 as well as in 2016 to cover the whole spring wheat growing season

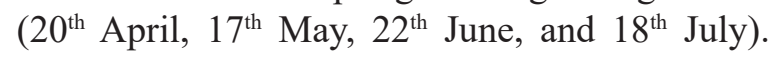
Thus, for the 2014 treatments, sampling occurred 1, 2, 3 and 4 months after biochar application, while in 2016 treatments, sampling was conducted 26, 27, 28 and 29 months after biochar application. Soil samples were dried at laboratory temperature and grinded. We determined the $\mathrm{pH}_{\mathrm{H} 2 \mathrm{O}}$ and $\mathrm{pH}_{\mathrm{KCl}}$ potentiometrically [Hanes 1999]. The $\mathrm{pH}$ in $\mathrm{H}_{2} \mathrm{O}$ and in $\mathrm{KCl}$ were determined with a soil:distiled water ratio of $1: 2.5\left(\mathrm{~g} \mathrm{~mL}^{-1}\right)$ and with a soil:solution of $1 \mathrm{M} \mathrm{KCl}$ ratio of 1:2.5 $\left(\mathrm{g} \mathrm{mL}^{-1}\right)$ using a WTW inoLab pH 730.

Obtained data was analyzed by using the statistic software Statgraphics Centurion XV.I (Stat-

Table 1. The investigated treatments

\begin{tabular}{|c|l|}
\hline Treatment & \\
\hline B0N0 & no biochar, no N fertilization \\
\hline B10N0 & biochar at rate of $10 \mathrm{t} \mathrm{ha}^{-1}$ \\
\hline B20N0 & biochar at rate of $20 \mathrm{t} \mathrm{ha}^{-1}$ \\
\hline B10N40 & biochar at rate of $10 \mathrm{t} \mathrm{ha}^{-1}$ with $40 \mathrm{~kg} \mathrm{~N} \mathrm{ha}^{-1}$ \\
\hline B20N40 & biochar at rate of $20 \mathrm{t} \mathrm{ha}^{-1} 40 \mathrm{~kg} \mathrm{~N} \mathrm{ha}^{-1}$ \\
\hline B10N80 & biochar at rate of $10 \mathrm{t} \mathrm{ha}^{-1}$ with $80 \mathrm{~kg} \mathrm{~N} \mathrm{ha}^{-1}$ \\
\hline B20N80 & biochar at rate of $20 \mathrm{t} \mathrm{ha}^{-1}$ with $80 \mathrm{~kg} \mathrm{~N} \mathrm{ha}^{-1}$ \\
\hline
\end{tabular}


point Technologies, Inc., USA). One-way ANOVA model was used for individual treatment comparisons at $P<0.05$, with separation of means by LSD multiple-range test. To evaluate the trends of the soil $\mathrm{pH}$ during investigated period, the MannKendall test and simple linear model were used.

\section{RESULTS AND DISCUSSION}

In this study, the addition of biochar to soil increased overall $\mathrm{pH}_{\mathrm{H} 2 \mathrm{O}}$ and the increase was highest for the treatment where biochar was applied at rate of $10 \mathrm{tha}^{-1}$ together with $\mathrm{N}$ fertilization in dose $40 \mathrm{~kg} \mathrm{ha}^{-1}$ (Fig. 1a). The treatments increased the $\mathrm{pH}$ in the following order B0N0 $<\mathrm{B} 10 \mathrm{~N} 80<\mathrm{B} 10 \mathrm{~N} 0<\mathrm{B} 20 \mathrm{~N} 40<\mathrm{B} 20 \mathrm{~N} 80=$ $\mathrm{B} 20 \mathrm{~N} 0<\mathrm{B} 10 \mathrm{~N} 40$. Soil $\mathrm{pH}_{\mathrm{H} 2 \mathrm{O}}$ values in biochar (including $\mathrm{N}$ fertilization) treatments (except $\mathrm{B} 10 \mathrm{~N} 0$ and $\mathrm{B} 10 \mathrm{~N} 80$ ) were significantly higher than $\mathrm{pH}_{\mathrm{H} 2 \mathrm{O}}$ of control treatment. Effects of $\mathrm{N}$ fertilization in biochar treatments compared to bio- char treatments were no observed. Paz-Ferreiro et al. [2014] found a lack of correlation between the initial biochar $\mathrm{pH}$ and the final $\mathrm{pH}$ of the biocharsoil mixture. A reason for the complex acid-basic equilibrium following biochar addition to the soil could lie in the mixture of organic and inorganic functional groups of alkali present in the biochar, which are dependent on the conditions of biochar production [Yuan et al. 2011]. The $\mathrm{pH}$ of biochar, similar with the other properties, is influenced by the type of feedstock, production temperature, and production duration [Liu et al. 2012]. The higher $\mathrm{pH}$ of the high temperature biochars is attributed to the accumulation of alkaline metals, formation of carbonates, and concentration of biomass-derived carbonates as a function of temperature [DeLuca et al. 2009, Yuan et al. 2011], which was also reflected in the higher ash contents in biochars produced at $600{ }^{\circ} \mathrm{C}$. Pyrolysis leads to the accumulation of alkaline substances on the biochar surface, which increases the soil pH [Butterly et al. 2009]. In our case biochar

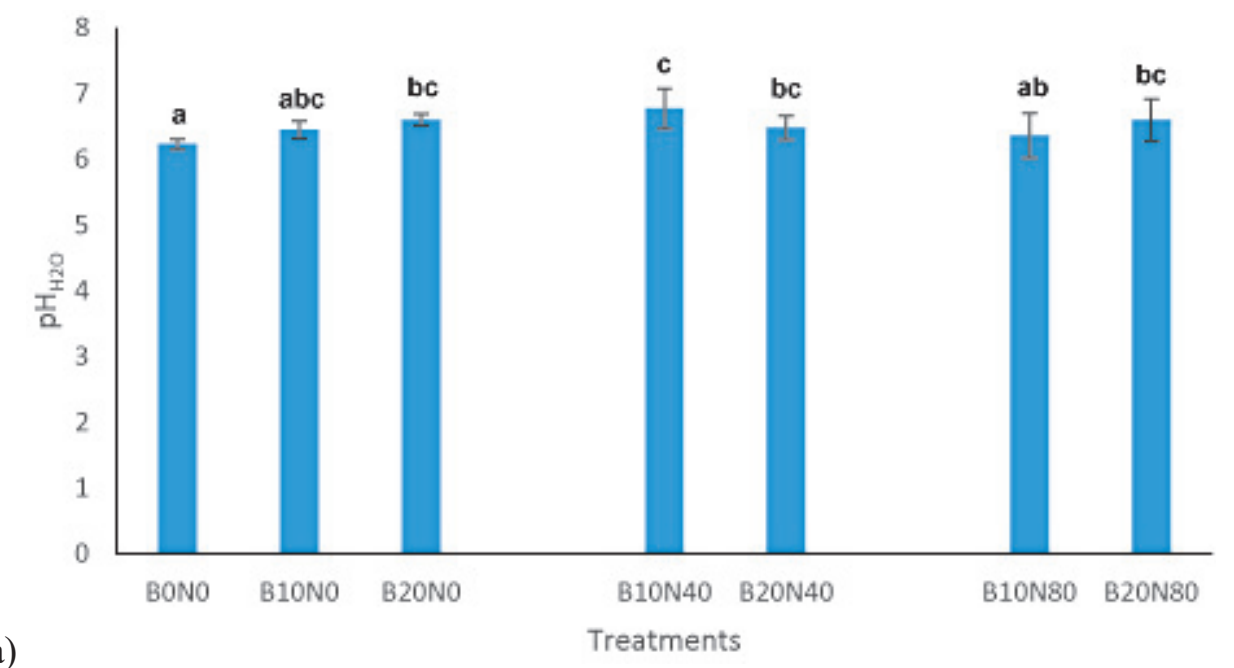

a)

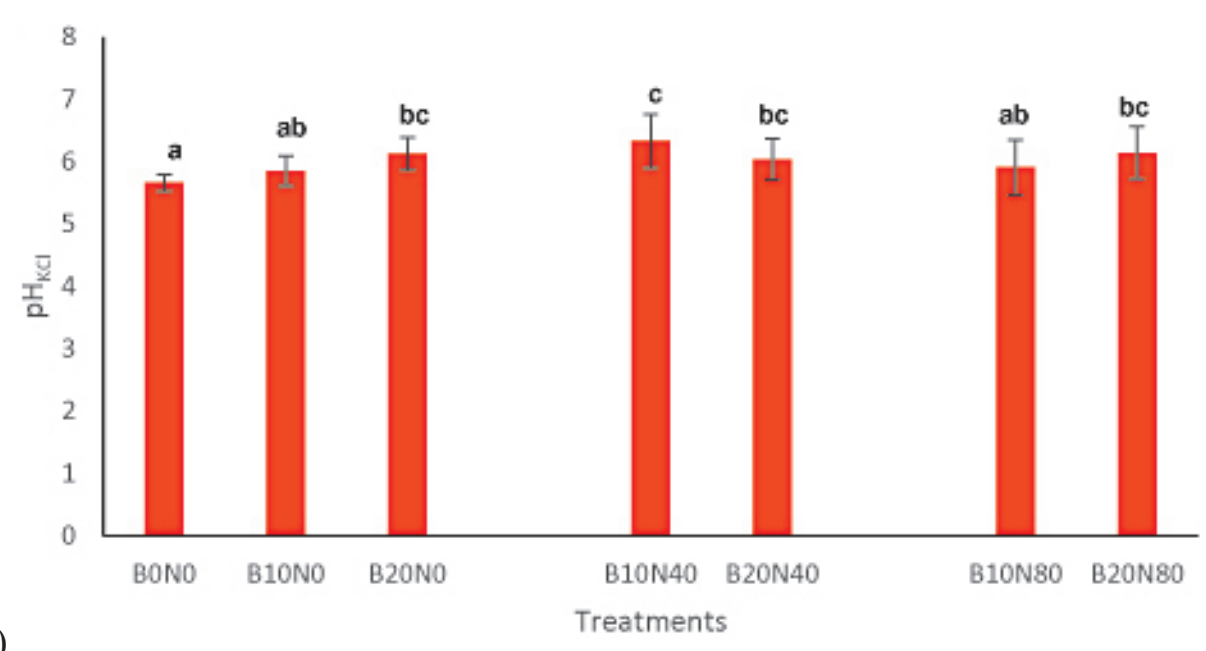

Fig. 1. Statistical evaluation of a) soil $\mathrm{pH}$ in $\mathrm{H}_{2} \mathrm{O}$, and b) soil $\mathrm{pH}$ in $\mathrm{KCl}$ 
used in the experiment was produced from the paper fiber sludge and grain husks by pyrolysis at $550^{\circ} \mathrm{C}$ for 30 minutes in a Pyreg reactor. On average; it contained $57 \mathrm{~g} \mathrm{~kg}^{-1}$ of Ca, $3.9 \mathrm{~g} \mathrm{~kg}^{-1}$ of $\mathrm{Mg}, 15 \mathrm{~g} \mathrm{~kg}^{-1}$ of $\mathrm{K}$ and $0.77 \mathrm{~g} \mathrm{~kg}^{-1}$ of $\mathrm{Na}$. On average, the biochar $\mathrm{pH}$ was 8.8 . Initial soil $\mathrm{pH}$ on average was 5.71 - slightly acidic and our results confirmed the findings of other authors recording neutralizing effect of biochar in the soils [Jeffery et al. 2011, Kim et al. 2015]. The same effects were observed in case of soil $\mathrm{pH}_{\mathrm{KCl}}$ (Fig. 1b). The B20N0, B10N40, B20N40 and B20N80 treatments significantly increased $\mathrm{pH}$ from 5.66 to $6.13,6.33,6.04$ and 6.14 , respectively. Oneway ANOVA analysis showed no significant differences in soil $\mathrm{pH}_{\mathrm{KCl}}$ between B10N0, B10N80 and control treatment (B0N0). Statistical significant differences in soil $\mathrm{pH}_{\mathrm{KCl}}$ between treatments with applied biochar and treatments with biochar and $\mathrm{N}$ fertilization were determined only in case of B10N40 and B10N0.

The dynamics of soil $\mathrm{pH}_{\mathrm{H} 2 \mathrm{O}}$ showed a stable trend with time during investigated period in control and treatments with applied biochar at the rate of 10 and $20 \mathrm{t} \mathrm{ha}^{-1}$ as well as in treatment with biochar in dose of $10 \mathrm{tha}^{-1}$ combined with $40 \mathrm{~kg} \mathrm{~N}$ ha-1. However, in B20N40 and treatments at both biochar application rates $\left(10\right.$ and $\left.20 \mathrm{t} \mathrm{ha}^{-1}\right)$ with $80 \mathrm{~kg} \mathrm{~N} \mathrm{ha}^{-1}$ showed a decreasing trend with the time according to the results of the Mann-Kendall test. In B10N0, $\mathrm{B} 10 \mathrm{~N} 40, \mathrm{~B} 20 \mathrm{~N} 40$ and $\mathrm{B} 10 \mathrm{~N} 80$ treatments, soil $\mathrm{pH}_{\mathrm{H} 2 \mathrm{O}}$ was increasing (during vegetation season 2014) after the application of biochar and during the next investigated period (vegetation season 2016) the soil $\mathrm{pH}_{\mathrm{H} 2 \mathrm{O}}$ was decreasing, however, statistically significant linear trend was observed only in case of B20N40. Several authors [DeLuca et al. 2009, Yuan et al. 2011, Rajkovich et al. 2012] pointed out on the fact that in ash of biochar are high levels of $\mathrm{Ca}^{2+}$ and $\mathrm{Mg}^{2+}$ and other alkaline elements, which are responsible for current neutralizing effect, but in the future they (alkaline elements) can increase the intensity of physico-chemical sorption of soil resulting in decrease in soil $\mathrm{pH}_{\mathrm{KCl}}$. Biochar is very stable in soil compared to other organic matter additions [Fischer and Glaser 2012]. Management practices such as addition of labile C (e.g. slurry) to soil significantly increased biochar mineralization [Kuzyakov et al. 2009]. After addition to soils, non-aromatic $\mathrm{C}$ fractions in biochar are potentially oxidized [Nguyen et al. 2010], which leads to subsequent decline in soil $\mathrm{pH}$ [Joseph et al. 2010]. Additionally, nitrification may also contribute to the decrease in $\mathrm{pH}$ [Horák et al. 2017]. Above mentioned findings confirms our results (Table 2). The dynamics of soil $\mathrm{pH}_{\mathrm{KCl}}$ showed a decreasing trend with time in all treatments including control according to the results of the Mann-Kendall test. Statistically significant linear trends were observed in treatments with applied biochar in both rates as well as in treatment with applied lower dose of biochar with combination of higher dose of $\mathrm{N}$ and opposite in treatment with applied higher dose of biochar with lower $\mathrm{N}$ fertilization.

\section{CONCLUSION}

Overall, biochar is a soil additive that increased the soil $\mathrm{pH}$. This effect (on soil $\mathrm{pH}$ in $\mathrm{H}_{2} \mathrm{O}$ and in $\mathrm{KCl}$ ) was the most intense after application of biochar at rate of $10 \mathrm{t} \mathrm{ha}^{-1}$ in combination with $40 \mathrm{~kg}$ $\mathrm{ha}^{-1}$ of nitrogen. Higher dose of biochar to the soil without $\mathrm{N}$ fertilization resulted in higher increase of soil $\mathrm{pH}$. During whole period, after application of biochar and biochar with $\mathrm{N}$ fertilization the val-

Table 2. Dynamics of soil $\mathrm{pH}$ according to the results of the Mann-Kendall test and correlation coefficient (linear model)

\begin{tabular}{|c|c|c|c|c|}
\hline \multirow{2}{*}{ Treatment } & \multicolumn{2}{|c|}{$\mathrm{pH}$} & \multicolumn{2}{c|}{$\mathrm{pH}$} \\
\cline { 2 - 5 } & $\mathrm{H}_{2} \mathrm{O}$ & $\mathrm{KCl}$ & $\mathrm{H}_{2} \mathrm{O}$ & $\mathrm{KCl}$ \\
\cline { 2 - 5 } & \multicolumn{2}{|c|}{ Mann-Kendall trends: 8 quarter evaluation } & 0.439 & 0.568 \\
\hline B0N0 & Stable / no trend & Decreasing & 0.413 & $0.725^{*}$ \\
\hline B10N0 & Stable / no trend & Decreasing & 0.550 & $0.910^{* *}$ \\
\hline B20N0 & Stable / no trend & Decreasing & 0.379 & 0.484 \\
\hline B10N40 & Stable / no trend & Decreasing & $0.747^{*}$ & $0.828^{*}$ \\
\hline B20N40 & Decreasing & Decreasing & 0.649 & $0.754^{*}$ \\
\hline B10N80 & Decreasing & Decreasing & 0.424 & 0.600 \\
\hline B20N80 & Decreasing & Decreasing & $(\mathrm{r})$ \\
\hline
\end{tabular}

$\mathrm{B} 0 \mathrm{~N} 0$ - no biochar, no $\mathrm{N}$ fertilization, B10N0 - biochar at rate of $10 \mathrm{t} \mathrm{ha}^{-1}$, B20N0 - biochar at rate of $20 \mathrm{t} \mathrm{ha}^{-1}$, $\mathrm{B} 10 \mathrm{~N} 40$ - biochar at rate of $10 \mathrm{tha}^{-1}$ with $40 \mathrm{~kg} \mathrm{~N} \mathrm{ha}^{-1}, \mathrm{~B} 20 \mathrm{~N} 40$ - biochar at rate of $20 \mathrm{tha}^{-1} 40 \mathrm{~kg} \mathrm{~N} \mathrm{ha}^{-1}, \mathrm{~B} 10 \mathrm{~N} 80$ - biochar at rate of $10 \mathrm{t} \mathrm{ha}^{-1}$ with $80 \mathrm{~kg} \mathrm{~N} \mathrm{ha}^{-1}$, B20N80 - biochar at rate of $20 \mathrm{t} \mathrm{ha}^{-1}$ with $80 \mathrm{~kg} \mathrm{~N} \mathrm{ha}^{-1}$. 
ues of $\mathrm{pH}_{\mathrm{KCl}}$ were gradually decreased in all biochar and biochar with $\mathrm{N}$ fertilization treatments. No significant linear decreasing trends were observed only after application biochar at rate $10 \mathrm{t} \mathrm{ha}^{-1}$ with $40 \mathrm{~kg}$ $\mathrm{N} \mathrm{ha}^{-1}$ as well as in treatment with biochar at rate 20 t ha-1 together with $80 \mathrm{~kg}^{-1} \mathrm{ha}^{-1}$ of nitrogen. In other words, lower dose of biochar with lower dose of $\mathrm{N}$ and on the other hand, higher dose of biochar with higher dose of $\mathrm{N}$ fertilization can be used to amend acidic soils in this region, but the effectiveness will decrease with time after its application. Thus, application of biochar to the soil does not address treatment of acidic soils for a longer period of time.

\section{Acknowledgements}

Project is supported by the Slovak Grant Agency VEGA No. 1/0136/17 and KEGA No. 0145PU-4/2016.

\section{REFERENCES}

1. Butterly C.R., Bünemann E.K., McNeill A.M., Baldock J.A., Marschner P. 2009. Carbon pulses but not phosphorus pulses are related to decreases in microbial biomass during repeated drying and rewetting of soils. Soil Biology and Biochemistry, 41(7), 1406-1416.

2. Čurlík J., Bedrna Z., Hanes J., Holobradý K., Hrtánek B., Kotvas F., Masaryk Š., Paulen J. 2003. Soil reaction and its modification. Suma print, Bratislava (in Slovak).

3. DeLuca T.H., MacKenzie M.D., Gundale M.J. 2009. Biochar effects on soil nutrient transformations. In: Lehmann J., Joseph S. (Eds.), Biochar for Environmental Management. Science and Technology. Earthscan, London, Sterling, VA, pp. 251-270.

4. Fecenko J., Ložek O. 2000. Nutrition and fertilization of field crops. Slovak University of Agriculture, Nitra (in Slovak).

5. Fischer D., Glaser, B. 2012. Synergisms between Compost and Biochar for Sustainable Soil Amelioration. In: Kumar S. (Ed.) Management of Organic Waste. Earthscan, Rijeka, pp. 167-198.

6. Hanes J. 1999. Analyzes of sorptive characteristics. SSCRI, Bratislava (in Slovak).

7. Horák J. 2015. Testing biochar as a possible way to ameliorate slightly acidic soil at the research field located in the Danubian lowland. Ac. Horti. Reg., 18(1), 20-24.

8. Horák J., Kondrlová E., Igaz D., Šimanský V., Felber R., Lukac M., Balashov E., Buchkina N., Rizhiya E.Y., Jankowski M. 2017. Quantification of the effects of biochar and biochar with N-fertilizer in Haplic Luvisol. In Biologia - in print
9. Jeffery S., Verheijen F.G.A., van der Velde M., Bastos A.C. 2011. A quantitative review of the effects of biochar application to soils on crop productivity using meta-analysis. Agr. Ecosyst. Environ., 144, 175-187.

10. Jones D.L., Rousk J., Edwards-Jones G., DeLuca T.H., Murphy D.V. 2012. Biochar-mediated changes in soil quality and plant growth in a three year field trial. Soil Biol. Biochem., 45, 113-124.

11. Joseph S.D., Camps-Arbestain M., Lin Y., Munroe P., Chia C.H., Hook J., van Zwieten L., Kimber S., Cowie A., Singh B.P., Lehmann J., Foidl N., Smernik R.J., Amonette J.E. 2010. An investigation into the reactions of biochar in soil. Soil Res., 48, 501-515.

12. Kim H.S., Kim K.R., Kim H.J., Kim K.H., Yang J.E., Ok Y.S., Owens G. 2015. Effect of biochar on heavy metal immobilization and uptake by lettuce (Lactuca sativa L.) in agricultural soil. Environ. Earth Sci., 74, 1-11.

13. Kuzyakov Y., Subbotina I., Chen H., Bogomolova I., Xu X. 2009. Black carbon decomposition and incorporation into soil microbial biomass estimated by 14C labeling. Soil Biol. Biochem., 41, 210-219.

14. Liu X.H., Zhang X.Ch. 2012. Effect of biochar on $\mathrm{pH}$ of alkaline soils in the loess plateau: results from incubation experiments. Int. J. Agric. Biol. 14, 745-750.

15. Millar C.E. Turk L.M., Foth H.D. 1962. Fundamentals of soil science. John Wiley and Sons, New York.

16. Paz-Ferreiro J., Lu H., Fu S., Mendez A., Gasco G. 2014. Use of phytoremediation and biochar to remediate heavy metal polluted soils: a review. Solid Earth, 5, 65- 75 .

17. Rajkovich S., Enders A., Hanley K., Hyland C., Zimmerman A.R., Lehmann J. 2012. Corn growth and nitrogen nutrition after additions of biochars with varying properties to a temperate soil. Biol. Fertil. Soils, 48, 271-284.

18. Šimanský V., Horák, J., Igaz D., Jonczak J., Markiewicz, M., Felber, R., Rizhiya, E.Y., Lukac M. 2016. How dose of biochar and biochar with nitrogen can improve the parameters of soil organic matter and soil structure? Biologia, 71(9), 989-995.

19. World Reference Base for Soil Resources. 2006. World Soil Resource Report No. 84. Food and Agriculture Organisation of the United Nations, Rome.

20. Yuan J.H., Xu R.K., Zhang H. 2011. The forms of alkalis in the biochar produced from crop residues at different temperatures. Bioresour. Technol., 102, 3488-3497.

21. Zhang A., Bian R., Pan G., Cui L., Hussain Q., Li L., Zheng J., Zheng J., Zhang X., Han X., Yu X. 2012. Effects of biochar amendments on soil quality, crop yield and greenhouse gas emission in a Chinese rice paddy: a field study of 2 consecutive rice growing cycles. Field Crop Res., 127, 153-160. 